\title{
ПОЛІМОРФІЗМ ГЕНІВ НЕЙРАМІНІДАЗИ ТА НУКЛЕОПРОТЕЇНУ ШТАМІВ ВІРУСУ ПТАШИНОГО ГРИПУ А Н1N1 I H7N9
}

Вступ. На сьогодні вірус грипу є основною причиною захворюваності людей будь-якого віку. Грип щорічно призводить до смерті значної кількості населення та завдає суттєвого економічного збитку. Вірулентність і патогенність цього вірусу значною мірою зумовлені наявністю в нього нейрамінідази та нуклеопротеїну, які забезпечують вірусну адгезію на клітині-хазяїні й реплікацію. Генетичний моніторинг $\epsilon$ важливим ключовим елементом епідеміологічного спостереження, яке включає в себе раннє виявлення та ідентифрікацію сезонних (циркулюючих) вірусів грипу, а також вірусів грипу нових підтипів, які можуть викликати пандемію. Для запобігання пандеміям необхідна інорормація про молекулярно-генетичний аналіз зразків вірусів грипу, рівень колективного імунітету, чутливість до противірусних препаратів, антигенні характеристики вірусу.

Мета дослідження - визначити молекулярно-генетичний поліморфізм генів нейрамінідази та нуклеопротеїну штамів вірусу пташиного грипу A H1N1 і H7N9 та його вплив на структуру доменів кодованих протеїнів біоінформатичними методами.

Методи дослідження. Було проаналізовано нуклеотидні послідовності генів нейрамінідази та нуклеопротеїну штамів вірусу грипу A H1N1 і H7N9, а також визначено домени продуктів цих генів за допомогою кластерного аналізу та програми DELTA-BLAST.

Результати й обговорення. За результатами дослідження, визначено поліморфізм і генетичні дистанції між алелями генів нейрамінідази та нуклеопротеїну итамів вірусу грипу A H1N1 і H7N9. Показано тип і локалізацію мутацій. Визначено домени продуктів досліджуваних нуклеотидних послідовностей. Показано роль і вплив мутацій у нуклеотидних послідовностях алелів досліджуваних генів на поліморфізм нейрамінідази та нуклеопротеїну.

Висновки. Визначено поліморфрізм генів нейрамінідази та нуклеопротеїну. Показано відсутність впливу поліморфізму нуклеотидних послідовностей генів нейрамінідази та нуклеопротеїну штамів вірусу грипу A H1N1 і H7N9 на доменовий склад цих протеїнів i, таким чином, на властивості даних итамів.

КЛЮчОВІ СлОВА: вірус грипу; нейрамінідаза; нуклеопротеїн; поліморфізм; штам H1N1; штам H7N9.

ВСТУП. Грип належить до гострих респіраторних вірусних інсрекцій та являє собою одну з найбільш значущих проблем, що стоять перед сучасною системою охорони здоров'я [1]. Епідемічний характер захворюваності на грип зумовлює ряд проблем соціального й економічного значень [2, 3].

Віруси грипу (з родини Orthomyхоviridae) $€$ однією з найбільш поширених причин виникнення респіраторних та шлунково-кишкових інорекцій людини. Віруси грипу поділяють на три типи A, В і С [2]. Значний ризик розвитку зоонозної інфекції створюють віруси грипу А. Вірулентність, патогенність і діапазон ураження вірусами грипу було достатньо досліджено. Так, виявлено вплив різноманітних чинників на ці показники $[4,5]$. Зокрема, вірусоспецифрічні детермінанти, кодовані вірусним геномом, було визначено як голов(c) С. В. Буряченко, Б. Т. Стегній, 2019. ні компоненти виживання вірусу та патогенезу. До них належать поверхневі протеїни - нейрамінідаза (NA), що забезпечує приєднання до клітини-хазяїна, а також фрактор реплікації нуклеопротеїнів (NP), які кодуються генами NA і NP відповідно [6-8]. Різні комбінації NA і NP зумовлюють різні підтипи вірусів грипу А. Високий ступінь поліморфрізму в цих РНК-вірусах спричинений надзвичайно великою швидкістю мутацій, що оцінюють як 0,01/нуклеотидний сайт/рік [9]. Рівень мінливості вірусів грипу значно ускладнює організацію профрілактичних заходів. Так, щороку розробляють десятки нових протигрипозних вакцин [2].

Мета дослідження - визначити молекулярно-генетичний поліморфізм генів нейрамінідази та нуклеопротеїну штамів вірусу пташиного грипу A H1N1 і H7N9 та його вплив на структуру доменів кодованих протеїнів. 
МЕТОДИ ДОСЛІДЖЕННЯ. Дослідження проводили на нуклеотидних послідовностях генів NA та NP штамів вірусу пташиного грипу А H1N1 і H7N9, отриманих з Національного центру біотехнологічної інформації (National Centre of Biotechnology Information) та Європейської молекулярно-біологічної лабораторії (European Molecular Biology Laboratory) [10, 11].

Кластерний аналіз та визначення генетичних дистанцій послідовностей досліджуваних генів проводили за допомогою програми MEGA 6 за алгоритмом ClustalW. Побудову дендрограми здійснювали методом максимальної правдоподібності (Maximum Likelihood Method), достовірність визначали методом бутстреп-аналізу, при якому число реплікацій дорівнювало 500 [12, 13]. Достовірним вважали результат, більший 70. Домени продуктів досліджуваних нуклеотидних послідовностей визначали за допомогою програми DELTA-BLAST [10].
Варіабельність генів NA та NP визначали за допомогою програми VectorNTI-11 методом локального вирівнювання нуклеотидних сиквенсів за Смітом - Ватерманом [14]. Мутації визначали відносно найбільших нуклеотидних послідовностей відповідних досліджуваних генів. Вплив поліморфізму генів нейрамінідази та нуклеопротеїну виявляли шляхом визначення доменів продуктів трансляції генів NA і NP за допомогою програми DELTA-BLAST [10]. Доступ до DELTABLAST та MEGA 6 вільний. У дослідженні використовували демоверсію VectorNTI-11, яка не потребує ліцензії.

РЕЗУЛЬТАТИ Й ОБГОВОРЕННЯ. За РеЗУЛЬтатом кластерного аналізу нуклеотидних послідовностей гена NA штамів вірусу грипу A H1N1 та H7N9 побудовано дендрограму (рис. 1).

Побудована дендрограма містить два кластери, кожен з яких складається з двох гілок. Одна

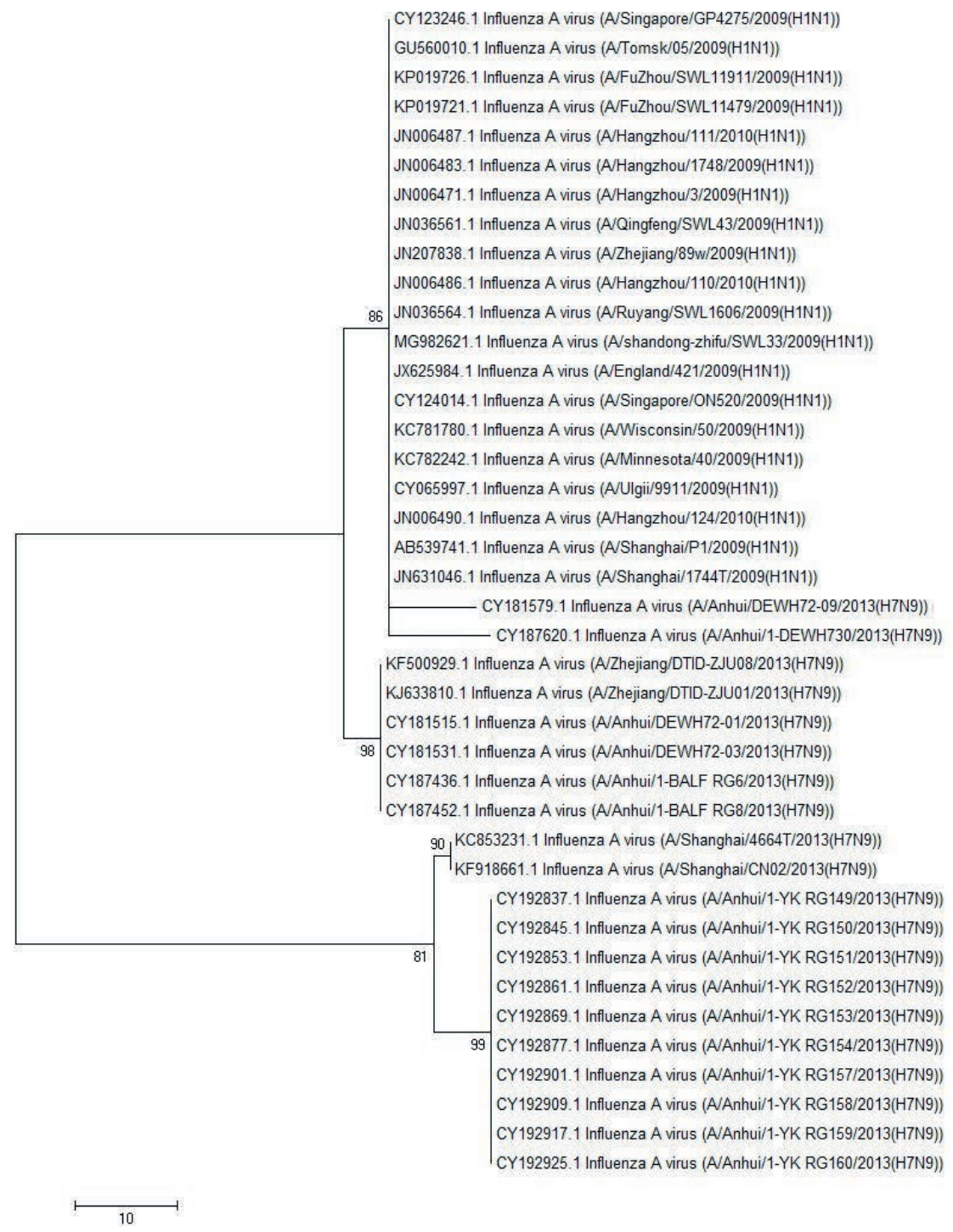

Рис. 1. Кластерний аналіз нуклеотидних послідовностей гена нейрамінідази штамів вірусу грипу А H1N1 та H7N9. Цифри на вузлах гілок вказують значення бутстреп-аналізу. 
гілка першого кластеру містить нуклеотидні послідовності штамів H1N1 та H7N9, інша - штаму H7N9. Другий кластер утворює лише послідовність штаму H7N9.

Розташування нуклеотидних послідовностей на дендрограмі вказує на низький поліморфізм гена NA штаму H1N1. Більшість зразків цього штаму, за двома винятками, є ідентичними за послідовностями гена $N A$. Поліморфізм гена $N A$ штаму H7N9 більш виражений, про що свідчить їх розташування в різних кластерах. Нуклеотидні послідовності штаму H7N9 утворюють три гілки у двох кластерах. Усередині кожної гілки відсутній генетичний поліморфізм.

За результатом кластерного аналізу нуклеотидних послідовностей гена NP штамів вірусу грипу A H1N1 та H7N9 побудовано дендрограму (рис. 2).

Побудована дендрограма містить два кластери. Перший кластер складається з нуклеотид- них послідовностей штамів вірусу грипу A H1N1 та H7N9, другий - з послідовностей штаму H1N1.

У результаті здійсненого кластерного аналізу не виявлено поліморфізму нуклеотидних послідовностей гена NP штаму вірусу грипу H7N9, які утворюють на побудованій дендрограмі окрему гілку разом з однією послідовністю штаму H1N1. Проте виявлено високий поліморорізм послідовностей штаму H1N1, які утворюють окремий кластер з генетично ідентичних зразків, та спільний кластер з послідовностями штаму вірусу грипу H7N9.

Показники бутстреп-аналізу на побудованих дендрограмах - понад 70, що вказує на достовірність розподілу досліджуваних нуклеотидних послідовностей.

Результати дослідження поліморфізму генів $N A$ та NP методом локального вирівнювання за допомогою програми VectorNTI-11 наведено в таблиці.

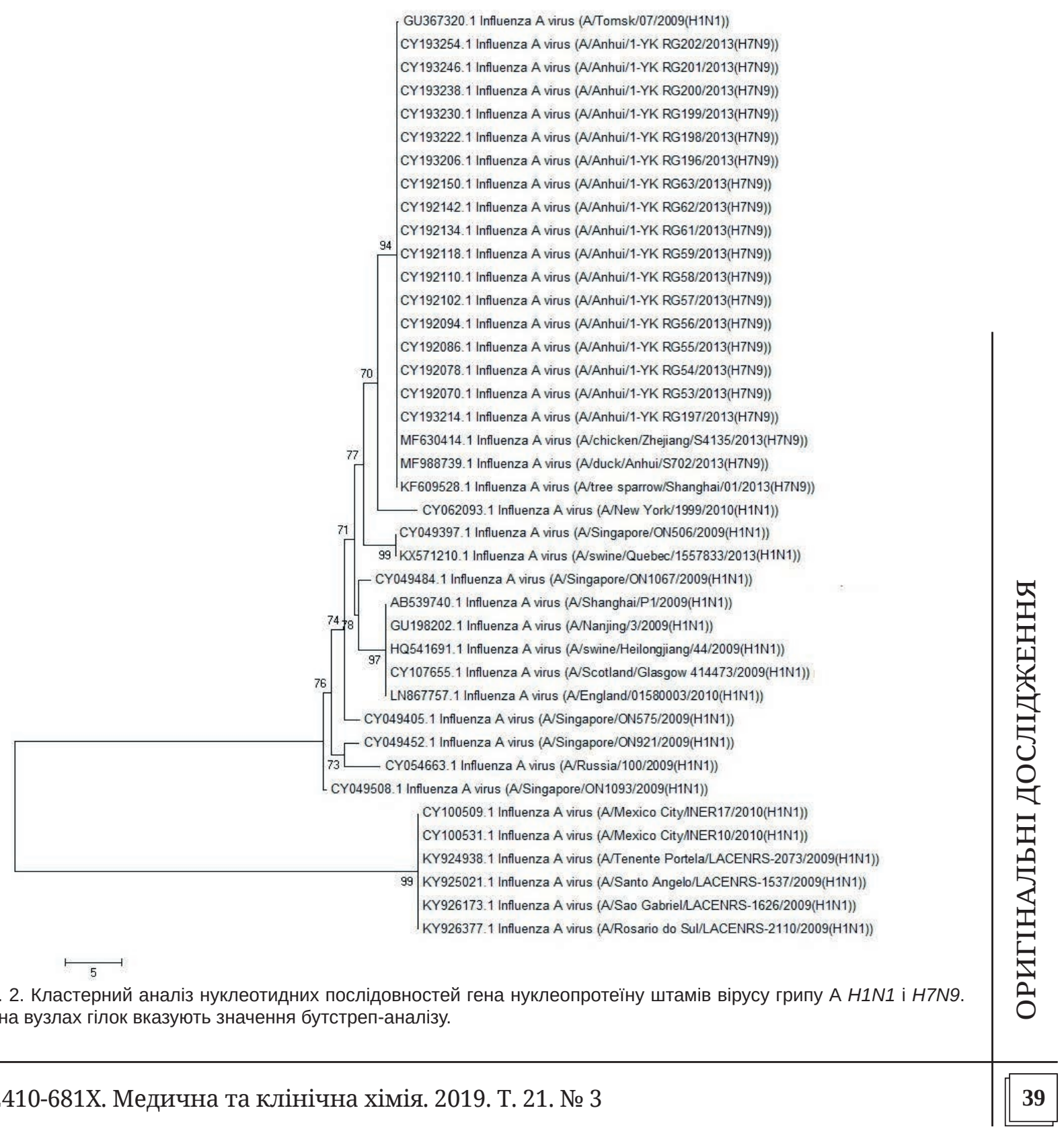


Таблиця - Поліморфізм генів нейрамінідази та нуклеопротеїну штамів вірусу пташиного грипу А H1N1 і H7N9

\begin{tabular}{|c|c|c|c|}
\hline Ген & $\begin{array}{l}\text { Нуклеотидна } \\
\text { послідовність }\end{array}$ & Ділянка гена (позиція нуклеотиду 3'-5') & Тип поліморсрізму \\
\hline \multirow[t]{3}{*}{$N A$} & \multirow[t]{3}{*}{ CY123246.1 } & $\begin{array}{l}\text { 1-20, 146-148, 161-162, 241, 791, 934, 973-974, } \\
\text { 1022-1025, 1043-1044, 1053, 1183, 1368, 1385, } \\
1401,1435,1461-1480\end{array}$ & Делеція \\
\hline & & $\begin{array}{l}\text { 110, 183, 195-196, 210-212, 222-227, 276, 292-297, } \\
782,1204,1267-1268,1281-1284\end{array}$ & Інсерція \\
\hline & & Рівномірно вздовж всієї послідовності & Індел \\
\hline \multirow[t]{2}{*}{ NP } & \multirow[t]{2}{*}{ CY100531 } & $1-45,1543-1565$ & Делеція \\
\hline & & Рівномірно вздовж всієї послідовності & Індел \\
\hline
\end{tabular}

Ген NA у вірусу грипу є більш поліморонним, ніж NP, що відображено на дендрограмах. Найбільш розповсюдженими мутаціями є делеції та однонуклеотидні заміни (індели). Останні являють собою найбільш поширену мутацію вірусів. Відсутність інсерцій у найдовшої нуклеотидної послідовності гена NP CY100531 вказує на еволюцію цього гена. Такий кількісний та якісний склад мутацій може бути зумовлений дрейфом і/або реасортацією (пересортуванням) генів вірусу грипу.

За результатами аналізу продуктів трансляції, всі досліджувані нуклеотидні послідовності гена NA штамів вірусу пташиного грипу A H1N1 та H7N9 містили один домен pfam00064, тоді як послідовності гена NP - домен pfam00506 (рис. 3). Домен pfam00064 бере участь у розщепленні кінцевих залишків сіалової кислоти, а домен pfam00506 зумовлює побудову капсиду навколо вірусної РНК [15].

За результатами аналізу за допомогою програми DELTA-BLAST, не виявлено впливу поліморфізму генів NA та NP штамів вірусу пташиного грипу A H1N1 і H7N9 на наявність доменів у продуктів трансляції цих генів.
3 літератури відомо, що штами H1N1 і H7N9 мають різні контагіозні, вірулентні та патогенні властивості. Оскільки поліморфізм доменів продуктів генів NA та NP даних штамів відсутній, вочевидь, тут має місце різний рівень трансляції цих генів.

У даному дослідженні показано рівень поліморфрізму генів NA та NP штамів вірусу пташиного грипу A H1N1 і H7N9 та його вплив на варіабельність нейрамінідази і нуклеопротеїну. Визначено локалізацію мутацій та їх тип на досліджуваних нуклеотидних послідовностях. За результатами дослідження, ген NP більш поліморфний у штаму H1N1, а ген NA - у штаму H7N9.

Дослідження доменів продуктів трансляції аналізованих нуклеотидних послідовностей виявило відсутність поліморфізму за доменовим складом і, таким чином, відсутність впливу поліморфрізму нуклеотидних послідовностей генів NA та NP штамів вірусу пташиного грипу A H1N1 і H7N9 на біохімічні властивості нейрамінідази та нуклеопротеїну в цих штамів.

Результати дослідження визначають еволюцію генів NA та NP і вказують на можливість

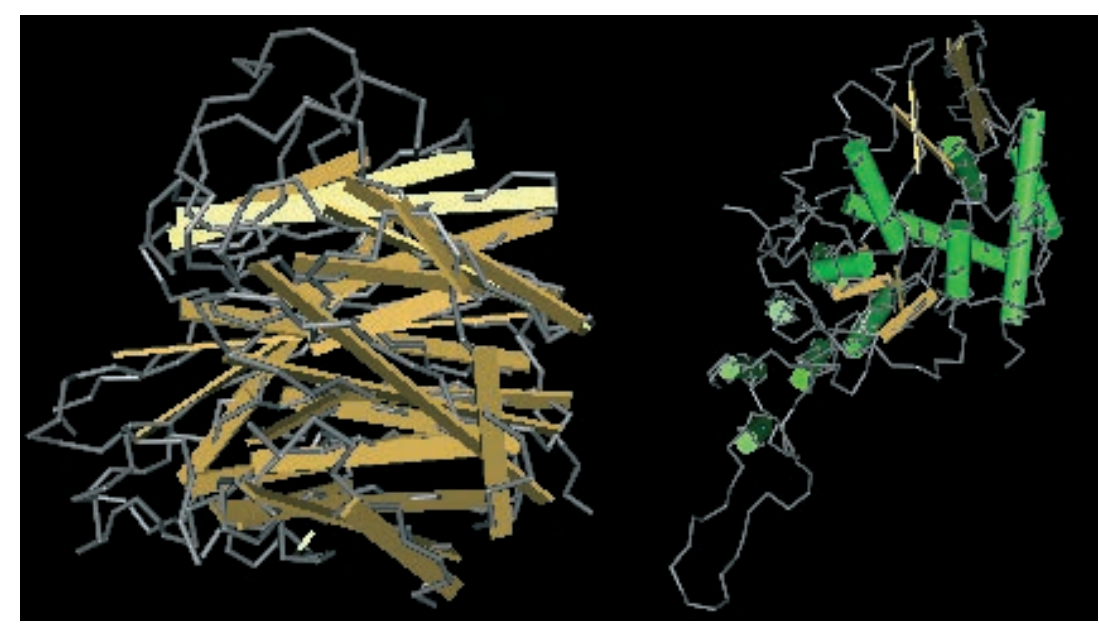

a

b

Рис. 3. Структури доменів pfam00064 (a) і pfam00506 (b), побудовані за результатом аналізу нуклеотидних послідовностей генів нейрамінідази та нуклеопротеїну штамів вірусу пташиного грипу A H1N1 та H7N9 за допомогою програми DELTA-BLAST. 
трансляційної і посттрансляційної модифрікації нейрамінідази та нуклеопротеїну. Всі результати $€$ статистично достовірними.

ВИСНОВКИ. 1. За результатами дослідження, визначено поліморфізм генів нейрамінідази та нуклеопротеїну.

\section{СПИСОК ЛІТЕРАТУРИ}

1. Ozawa M. Crosstalk between animal and human influenza viruses /M. Ozawa, Y. Kawaoka // Annu. Rev. Anim. Biosci. - 2013. - No. 1. - P. 21-42.

2. Cyclic avian mass mortality in the Northeastern United States is associated with a novel orthomyxovirus // A. B. Allison, J. R. Ballard, R. B. Tesh [et al.] // J. Virol. 2015. - No. 89 (2). - P. 1389-1403.

3. Taubenberger J. K. Influenza Virus Evolution, Host Adaptation and Pandemic Formation / J. K. Taubenberger J. C. Kash // Cell Host Microbe. - 2010. - No. 7 (6). P. 440-451.

4. Staats C. B. Diversity of influenza viruses in swine and the emergence of a novel human pandemic influenza A (H1N1) / C. B. Staats, R. G. Webster, R. J. Webby // Influenza Other Respir Viruses. - 2009. - No. 3 (5). P. 207-213.

5. Webby R. J. Evolution and ecology of influenza A viruses / R. J. Webby, R. G. Webster // Curr. Top Microbiol. Immunol. - 2014. - 385. - P. 359-375. doi: 10.1007/82_2014_396.

6. Study of immunogenicity of recombinant proteins base don hemagglutinin and neuraminidase conservative epitopes of Influenza A virus / I. Dukhovlinov, R. AlShekhadat, E. Fedorova [et al.] // Med. Sci. Monit. Basic Res. - 2013. - No. 19. - P. 221-227.

7. Gamblin S. J. Influenza hemagglutinin and neuraminidase membrane glycoproteins / S. J. Gamblin J. J.Skehel // J. Biol. Chem. - 2010. - No. 285 (37). P. 28403-28409.

8. Emergence of avian influenza viruses with enhanced transcription activity by a single amino acid sub-
2. Показано відсутність впливу поліморфрізму нуклеотидних послідовностей генів нейрамінідази та нуклеопротеїну штамів вірусу грипу А H1N1 і H7N9 на доменовий склад цих протеїнів i, таким чином, на властивості даних штамів. stitutionin the nucleoprotein during replicationin chicken brains / T. Tada, K. Suzuki, Y. Sakurai [et al.] // J. Virol. 2011. - No. 85 (19). - P. 10354-10363.

9. Generation of a broadly reactive influenza $\mathrm{H} 1$ antigen using a consensus HA sequence / X. Ping, W. Hu, R. Xiong [et al.] // Vaccine. - 2018. - 36 (32 Pt B). - P. 4837-4845. doi: 10.1016/j.vaccine.2018.06.048. Epub 2018 Jun 28.

10. Forrest H. L. Perspectives on influenza evolution and the role of research / H. L. Forrest, R. G. Webster // Anim. Health Res. Rev. - 2010. - 11 (1). - P. 3-18. doi: $10.1017 /$ S1466252310000071.

11. QiX. Swine influenza virus: evolution mechanism and epidemic characterization-a review / X. Qi, C. Lu // Wei Sheng Wu Xue Bao. -2009. - 49 (9). - P. 1138-1145.

12. Fang K. Analyzing large datasets with bootstrap penalization / K. Fang, S. Ma // Biom. J. - 2017. - 59 (2). P. 358-376. doi: 10.1002/bimj.201600052. Epub 2016 Nov 21.

13. Tamura K. MEGA5: Molecular evolutionary genetics analysis using maximum likelihood, evolutionary distance, and maximum parsimony methods / K. Tamura, D. Peterson, N. Peterson // Mol. Biol. Evol. - 2011. No. 28 (10). - P. 2731-2739.

14. Smith S. Identification of common molecular subsequences / S. Smith, M. Waterman // Journal of Molecular Biology. - 1981. - No. 147. - P. 195-197.

15. Sauer A. Characterization of the sialic acid binding activity of influenza a viruses using soluble variants of the $\mathrm{H} 7$ and $\mathrm{H} 9 \mathrm{Hemagglutinins} / \mathrm{A}$. Sauer, C. Liang, J. Stech // PLoS One. - 2014. - No. 9 (2). - e. 89529.

\section{REFERENCES}

1. Ozawa, M.Y., \& Kawaoka, Y. (2013). Crosstalk between animal and human influenza viruses. Annu. Rev. Anim. Biosci., 1, 21-42.

2. Allison, A.B., Ballard, J.R., Tesh, R.B., Brown, J.D., Ruder, M.G., Keel, M.K., \& Dwyerj, C. (2015). Cyclic avian mass mortality in the Northeastern United States is associated with a novel orthomyxovirus. J. Virol., 89 (2), 1389-1403.

3. Taubenberger, J.K., \& Kash, J.C. (2010). Influenza virus evolution, host adaptation and pandemic formation. Cell Host Microbe, 7 (6), 440-451.
4. Staats, C.B., Webster, R.G., \& Webby, R.J. (2009). Diversity of influenza viruses in swine and the emergence of a novel human pandemic influenza A(H1N1). Influenza Other. Respir. Viruses, 3 (5), 207-213.

5. Webby, R.J., \& Webster, R.G. (2014). Evolution and ecology of influenza A viruses. Curr. Top Microbiol. Immunol., 3 (85), 359-375. doi: 10.1007/82 2014396.

6. Dukhovlinov, I., Al-Shekhadat, R., Fedorova, E., Stepanova, L., Potapchuk, M., Repko, I., Rusova, O., Orlov, A., \& Kiselev, L.O. (2013). Study of immunogenicity of recombinant proteins based on hemagglutin in and 
neuraminidase conservative epitopes of InfluenzaA virus. Med. Sci. Monit. Basic Res., 19, 221-227.

7. Gamblin, S.J., \& Skehel, J.J. (2010). Influenza hemagglutinin and neuraminidase membrane glycoproteins. J. Biol. Chem., 285 (37), 28403-28409.

8. Tada, T.K., Suzuki, Y., Sakurai, M., Kubo, H., Okada, T., \& Itoh, K. (2011). Tsukamoto emergence of avian influenza viruses with enhanced transcription activity by a single amino acid substitution in the nucleoprotein during replication in chicken brains. J. Virol., 85 (19), 10354-10363.

9. Ping, X., Hu, W., Xiong, R., Zhang, X., Teng, Z., Ding, M., Li, L., Chang, C., \& Xu K. (2018). Generation of a broadly reactive influenza $\mathrm{H} 1$ antigen using a consensus HA sequence. Vaccine, 36 (32 Pt B), 4837-4845. doi: 10.1016/j.vaccine.2018.06.048.

10. Forrest, H.L., \& Webster, R.G. (2010). Perspectives on influenza evolution and the role of research. Anim. Health Res. Rev., 11 (1), 3-18. doi: 10.1017/ S1466252310000071.
11. Qi, X., \& Lu, C. (2009). Swine influenza virus: evolution mechanism and epidemic characterization - a review. Wei Sheng Wu Xue Bao, 49 (9),1138-1145.

12. Fang, K., \& Ma, S. (2017). Analyzing large datasets with bootstrap penalization. Biom J., 59 (2), 358-376. doi: 10.1002/bimj.201600052.

13. Tamura, K.D., \& Peterson, N. (2011). Peterson MEGA5: Molecular evolutionary genetics analysis using maximum likelihood, evolutionary distance, and maximum parsimony methods, (2011). Mol. Biol. Evol., 28 (10), 2731-2739.

14. Smith, S.M. (1981). Waterman identification of common molecular subsequences. Journal of Molecular Biology, 147, 195-197.

15. Sauer, A., Liang, C., \& Stech, J. (2014). Characterization of the sialic acid binding activity of influenza A viruses using soluble variants of the $\mathrm{H} 7$ and $\mathrm{H} 9$ hemagglutinins PLoS One, 9 (2). e. 89529.

С. В. Буряченко, Б. Т. Стегний
ИНСТИТУТ ЭКСПЕРИМЕНТАЛЬНОЙ И КЛИНИЧЕСКОЙ ВЕТЕРИНАРНОЙ МЕДИЦИНЫ, ХАРЬКОВ

\section{ПОЛИМОРФИЗМ ГЕНОВ НЕЙРАМИНИДАЗЫ И НУКЛЕОПРОТЕИНА ШТАММОВ ВИРУСА ПТИЧЬЕГО ГРИППА А Н1N1 И Н7N9}

\section{Резюме}

Вступление. На сегодня вирус гриппа является основной причиной заболеваемости людей разного возраста. Грипп ежегодно приводит к смерти значительного количества населения и наносит существенный экономический ущерб. Вирулентность и патогенность этого вируса в значительной степени обусловлены наличием у него нейраминидазы и нуклеопротеина, которые обеспечивают вирусную адгезию на клетке-хозяине и репликацию. Генетический мониторинг является важным ключевым элементом эпидемиологического наблюдения, которое включает в себя раннее выявление и идентификацию сезонных (циркулирующих) вирусов гриппа, а также вирусов гриппа новых подтипов, которые могут вызвать пандемию. Для предотвращения пандемий необходима информация о молекулярно-генетическом анализе образцов вируса гриппа, уровне коллективного иммунитета, чувствительности к противовирусным препаратам, антигенных характеристиках вируса.

Цель исследования - определить молекулярно-генетический полиморфизм генов нейраминидазы и нуклеопротеина штаммов вируса птичьего гриппа A H1N1 и H7N9 и его влияние на структуру доменов кодированных протеинов биоинорормационными методами.

Методы исследования. Были проанализированы нуклеотидные последовательности генов нейраминидазы и нуклеопротеина штаммов вируса гриппа A H1N1 и H7N9, а также определены домены продуктов этих генов с помощью кластерного анализа и программы DELTA-BLAST.

Результаты и обсуждение. По результатам исследования, определены полиморфизм и генетические дистанции между аллелями генов нейраминидазы и нуклеопротеина штаммов вируса гриппа $A$ H1N1 u H7N9. Показаны тип и локализация мутаций. Определены домены продуктов исследуемых нуклеотидных последовательностей. Показаны роль и влияние мутаций в нуклеотидных последовательностях алеллей исследуемых генов на полиморфизм нейраминидазы и нуклеопротеина.

Выводы. Определен полиморфизм генов нейраминидазы и нуклеопротеина. Показано отсутствие влияния полиморфризма нуклеотидных последовательностей генов нейраминидазы и нуклеопротеина штаммов вируса гриппа A H1N1 и H7N9 на доменовый состав этих протеинов и, таким образом, на свойства данных штаммов.

КЛЮЧЕВЫЕ СЛОВА: вирус гриппа; нейраминидаза; нуклеопротеин; полиморфризм; штамм H1N1; штамм H7N9. 


\section{POLYMORPHISM OF NEURAMINIDASE AND NUCLEOPROTEIN ENCODING GENES OF INFLUENZA A H1N1 AND H7N9 STRAINS}

\section{Summary}

Introduction. Nowadays, the influenza virus is the main cause of diseases for people of all ages, annually leading to death and causing significant economic damage. The virulence and pathogenicity of this virus are largely due to the presence of neuraminidase and a nucleoprotein that provide its adhesion to the host cell and replication. Genetic monitoring is an important key element of epidemiological surveillance, which includes the early detection and identification of seasonal (circulating) influenza viruses, as well as influenza viruses of new subtypes that may cause a pandemic. The precise information including molecular genetic analysis of influenza viruses, level of collective immunity, study of susceptibility to antiviral drugs, antigenic characteristics of the virus appears to be strongly required.

The aim of the study - to determine the molecular genetic polymorphism of the neuraminidase and nucleoprotein genes of the avian influenza A H1N1 and H7N9 strains and to determine its effect on the structure of coded protein domains by bioinformatics methods.

Research Methods. The nucleotide sequences of the neuraminidase and nucleoprotein genes of the influenza A H1N1 and H7N9 strains were analyzed, as well as the domains of the studied gene product were analyzed by cluster analysis and the DELTA-BLAST program.

Results and Discussion. As a result of the accomplished study, the polymorphisms and genetic distances between the alleles of the neuraminidase and nucleoprotein genes of the influenza A strains A1N1 and H7N9 alleles were calculated. The type and localization of mutations was shown. The domains of the gene products of the studied nucleotide sequences were determined. The role and effect of codons in the nucleotide sequences of the alleles of genes, which areencoding neuraminidase and nucleoprotein, on neuraminidase and nucleoprotein was shown.

Conclusions. In the result of the accomplished studies there was determined the polymorphism of the neuraminidase and nucleoprotein genes. The absence of the effect of polymorphism of the nucleotide sequences of the neuraminidase and nucleoprotein genes of influenza A H1N1 and H7N9 strains on the domain composition of the studied proteins and, thus, on the properties of the studied strains was shown.

KEY WORDS: influenza virus; neuraminidase; nucleoprotein; polymorphism; H1N1 strain; H7N9 strain.

Отримано 08.08.19

Адреса для листування: С. В. Буряченко, Інститут експериментальної і клінічної ветеринарної медицини, вул. Пушкінська, 83, Харків, 61023, Україна, е-mail: semenb837@gmail.com. 